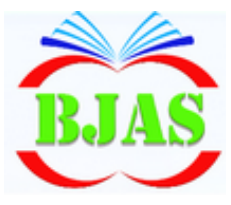

ISSN 1814 - 5868
Available online at http://bajas.edu.iq

https://doi.org/10.37077/25200860.2019.211 College of Agriculture, University of Basrah

Basrah J. Agric. Sci., 32(2): 213-222, 2019

\section{Basrah Journal of Agricultural Sciences}

E-ISSN: 2520-0860

\title{
study of the Optimal Conditions of Levan Production from a Local Iolate of Bacillus subtilis subsp. subtilis w36
}

\author{
Wafaa H. Khassaf ${ }^{1 *}$, Alaa K. Niamah ${ }^{2} \&$ Alaa J. A. Al-Manhel ${ }^{2}$ \\ ${ }^{1}$ Date Palm Research Centre, University of Basrah , Iraq \\ ${ }^{2}$ Department of Food Science, College of Agriculture, University of Basrah, Iraq \\ *Corresponding author E-mail: wafaakhissaf@gmail.com \\ Received 14 October 2019; Accepted 22 November 2019; Available online 31 December 2019
}

\begin{abstract}
The present study was aimed to test optimum conditions for the levan production from local isolation Bacillus subtilis subsp. subtilis w36, which was isolated from Basrah city soil by using production medium containing (40 $\mathrm{g}$ of sucrose as carbon source $10 \mathrm{~g}$ pepton, $1 \mathrm{~g}$ (NH4) 2SO4, 1g KH2PO4, $1 \mathrm{~g}$ $\mathrm{MgSO} 4.7 \mathrm{H} 2 \mathrm{O})$. The amount of levan produced was 4.9 g.ml-1. Molasses and date juice were used as substitutes for sucrose in growth media and substitute percentages were $(25 \%, 50 \%, 75 \%$ and $100 \%)$. The results showed the highest production of levan was recorded when sucrose was substituted with $25 \%$ molasses, which was 5.2 g.ml-1.Therefore, this medium was used to study optimum conditions included incubation period, inoculation volume, temperature ,initial $\mathrm{pH}$. The highest production of levan was $6.8 \mathrm{~g} .100 \mathrm{ml}-1$ within 40 hours' incubation, $1 \mathrm{ml}$ inoculum volume, $\mathrm{pH} 6.5$ and $32^{\circ} \mathrm{C}$.
\end{abstract}

Keywords:Bacteria, Bacillus subtilis, Molasses, Levan, Production, Optimal conditions.

\section{Introduction}

Several microbial polysaccharides commercially in use in food manufacturer are bacterial cellulose, mannan, bacterial alginates, xanthan gum, gellan gum, levan, and hyaluronic acid (Al-Manhel \& Niamah, 2017). Levan is an extracellular polysaccharide (EPS), and it is a natural mono-fructose sugar and Its biologically active (Tomulescu et al., 2016). Levan produced naturally from a wide range of microorganisms, especially bacteria, and some plant species. Its microbial source is better economically, artificially and applied aspects, in addition, bacteria produce levan in larger amounts of plants. Bacterial levans have a higher molecular weight $\left(2-100 \times 10^{6}\right)$ that produced from plants (200-33000 Dalton), (Srikanth et al., 2015 a). Levan sugar is composed of units of fructose that are bound together by $ß$-glycoside bonds $(2,6)$ and beta-branch $(1,2)$. The presence of sucrose in the medium in which bacteria grow stimulates the production of levan, where this enzyme analyzes the sucrose and converts fructose to levan sugar, this process is called "transfructosylation" (Srikanth et al., 2015b). Levan is an exopolysaccharide that synthesized from sucrose by levansucrase enzyme (EC 2.4.1.10), also called 6fructosyltransferase. It is an enzyme extracellular produced (Gu et al., 2017). Livan has many applications in food, 
industrial, technological and health fields, which use as a prebiotic compound in fraction food (Franken et al., 2013 ), Levan also has healthy properties as it is anti-cancer and antidiabetic, as well as anti-oxidant and antiinflammatory activities, In cosmetic processes and other therapeutic materials ( $\mathrm{Gu}$ et al., 2017). Bersaneti et al. (2018) reported that levan could be used as a blood plasma substitute and lower cholesterol in the body. In food, it used as a stabilizer, thickener, fat substitute and color and flavor vehicle (Dos Santos et al., 2013). Tomulescu et al. (2016) mentioned that levan used as industrial gums (gum Arabic) and fillers (Abou-Taleb et al., 2014), fat substitues (Santos et al., 2014), sweeteners (Dvya \& Sugumaran, 2015). Additionally, levan was used in the manufacture of biodegradable plastic that used in food packaging (Chen et al., 2014), and it used in the manufacture of lozenges Flavor Bearer and Packaging Factors (Divya \& Sugumaran, 2015).

The production of levan is influenced not only by the carbon source, but also by other fermentation conditions such as temperature, $\mathrm{pH}$, type of fermentation, cell growth rate and oxygen content in the fermentation medium (Ernandes \& Garcia-Cruz, 2005). Bacillus is one of the most important bacteria used in the production of microbial levan.

Different species of Bacillus genus were used to produced levan, such as $B$. licheniformis (Dahech et al., 2014), B. subtilis NATTO; (Gu et al., 2017), and B. subtilis B58 (Hamid et al., 2018). Due to the importance of levan and its wide applications in food and its role in the chemical and pharmaceutical industries, many studies were performed to improve the conditions of levan production, many attempts have been made to find a sucrose substitute as carbon sources, which were cheap and available locally. GojgicCvijovic et al. (2019) found that the molecular weight of levan produced from molasses was $5.82 \times 10^{6}$. Dalton and the viscosity was $0.24 \mathrm{dL} \cdot \mathrm{g}^{-1}$, levan produced from molasses were not significantly different from the levan produced from sucrose $200 \mathrm{~g}$. $\mathrm{L}^{-1}$.

This study was carried out to improve the production of levan by using a substitute productive medium from agricultural residues, ${ }^{-}$and from a local isolate of Bacillus subtilis subsp. subtilis w36.

\section{Materials \& Methods}

\section{Materials}

Nutrient agar medium, nutrient broth medium (Hi-media, India) ,Ammonium sulfate $\left(\mathrm{NH}_{4}\right)_{2} \mathrm{SO}_{4}$, potassium phosphate $\mathrm{KH}_{2} \mathrm{PO}_{4}$, $\mathrm{HCI}$ (England, PDH) sodium hydroxide $\mathrm{NaOH}$ magnesium sulfate $\mathrm{MgSO}_{4.7} \mathrm{H}_{2} \mathrm{O}$, (Germany, Merck), Peptone (USA, Difco), Ethanol (Spain, Scharlau).

\section{Bacteria used in the production of levan}

Bacillus subtilis subsp. subtilis w36 isolated from soil and characterized in a previously study, nutrient broth medium (Himedia, India) was used to activate the bacterial isolates in all tests.

\section{Methods}

\section{The fermentation process and the medium of levan production}

The fermentation process was carried out in $250 \mathrm{ml}$ flasks was contained100 $\mathrm{ml}$ of fermentation medium, which, consist of $40 \mathrm{~g}$

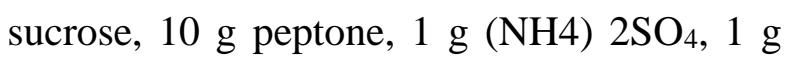
$\mathrm{KH}_{2} \mathrm{PO}_{4}$ and $1 \mathrm{~g} \mathrm{MgSO}_{4} .7 \mathrm{H} 2 \mathrm{O}$, adjusted $\mathrm{pH}$ to 6.8 , and was sterilized on $121{ }^{\circ} \mathrm{C}$ for 15 min. The flask was inoculated with $1 \mathrm{ml}$ inoculum and incubated at $32{ }^{\circ} \mathrm{C}$ for 60 hours (Meng \& Fütterer, 2003). 
Khassaf et al. / Basrah J. Agric. Sci., 32 (2): 223-232, 2019

\section{Extraction and purification of levan}

At the end of fermentation, the medium containing the levan was heated at $100{ }^{\circ} \mathrm{C}$ for $30 \mathrm{~min}$, then cooled and centrifuged for 30 min at $5000 \mathrm{rpm} .100 \mathrm{ml}$ of the supernatant was taken and heated for 5 minutes, then cooled at room temperature. Then $\mathrm{pH}$ value adjusted to 10 by using $1 \mathrm{~N} \mathrm{KOH}$. Levan was precipitated by adding 2 volumes of $80 \%$ cold ethanol $(\mathrm{V}: \mathrm{V})$, and then added $1 \% \mathrm{CaCl}_{2}$ with constant stirring for 20 minutes. The resulting pellets were washed with cold ethanol of $80 \%$ concentration at $1.5(\mathrm{~V}: \mathrm{V})$, then dried and weighed (Jathore et al., 2012).

Study of the optimum conditions of levan production

\section{Effect of carbon source on levan production}

Two local substitutes were used as a carbon sources in media production, sugar cane molasses (obtained from Maysan sugar production factory) and date juice extracted from date palm fruits (Zahdi is a local class) prepared in laboratory. According to AlSahlany \& Al-Asady (2015), the percentages of substitutes in the medium were $(25 \%, 50 \%$, $75 \%$ and $100 \%$ ) of carbon source. The total sugar in molasses was $65.5 \%$ and date juice was $38.5 \%$ that were determined by Lane and Eynon method described by Dalaly \& AlHakim (1987). Molass was purified by activated charcoal $(3 \% \mathrm{~W}: \mathrm{V})$, and then centrifuged at $5000 \mathrm{rpm}$ for $15 \mathrm{~min}$., then the supernatant was used in fermentation process (Gojgic-Cvijovic et al., 2019). Substitute percentages of molasses and date juice were added to $100 \mathrm{ml}$ of production medium and $\mathrm{pH}$ was adjusted to 6.8 , after that, incubated at $32{ }^{\circ} \mathrm{C}$ for 60 hours (Meng \& Fütterer, 2003). used an inoculum volume of $1 \mathrm{ml} .100 \mathrm{ml}^{-1}$ $\left(129 \times 10^{9}\right)$ colony forming units. $\mathrm{ml}^{-1}$.
Effect of different incubation periods on levan production

Many incubation periods were tested for levan production from the substitute media. The incubation periods were $20,40,60,80$ and100 hours, by using $1 \mathrm{ml}$ of inoculum volume of old isolate, other conditions of medium were an initial $\mathrm{pH} 6.8$ and $32{ }^{\circ} \mathrm{C}$, then the produced levan amount was calculated.

\section{Effect of inoculum volume on levan production}

Different inoculum volumes of a local isolate were used for levan production from the substitute media.The inoculum volumes were $(0.5,1,2$ and 3) $\mathrm{ml}$ for each $100 \mathrm{ml}$ culture media, initial $\mathrm{pH}$ was 6.8 . The cultures media were incubated at $32{ }^{\circ} \mathrm{C}$ for the optimum incubation period. Additionally, the number of bacteria was calculated in $1 \mathrm{ml}$ of inoculum volume was $\left(129 \times 10^{9}\right) \mathrm{CFU} \cdot \mathrm{ml}^{-1}$.

\section{Effect of incubation temperature on levan production}

Different temperature degrees $(25,32,37,45$ and 50$)^{\circ} \mathrm{C}$ were examined for the substitute media of levan production by local isolate, initial $\mathrm{pH}$ of media was 6.8 , other optimum conditions were used as the conditions of the levan production.

\section{Effect of initial pH on levan production}

To evaluate optimum $\mathrm{pH}$ for levan production from substitute media by local isolate, $\mathrm{pH}$ of production media was adjusted to $4,4.5,5$, $5.5,6,6.5,6.8,7.5$ and 8 by using $\mathrm{HCl}(0.2$ M) or $\mathrm{NaOH}(0.1 \mathrm{M})$. The optimal conditions were obtained from previous steps were used.

\section{Statistical Analysis}

The mean of the three values $(n=3)$ for all sample tests was calculated. One-way ANOVA table was applied to analyze the 
results by SPSS (version 18.0). The level of Significance was 0.05 to compare among the data means using Least Significant Difference (LSD). The diagram of this study was drawn by used Microsoft Excel (version 2013). Results were presented as means \pm standard deviations $( \pm \mathrm{SD})$.

\section{Results \& Discussion}

Production of levan from a local isolation of Bacillus subtilis subsp. subtilis w36

The results of this study showed that, levan production from production media (40\% sucrose) by local isolation of $B$. subtilis subsp. subtilis w36 was 4.9 g.100 ml-1. B. subtilis was characterized by its high production of levan compared to that of another species of bacteria. The result of this study was consistent with Shih et al. (2005) and Hamid et al. (2018). The amount of levan sugar produced from microorganisms depended on microbe used and the amount and type of sugar present in the production media.

\section{Effect of using different percentages of molasses and date juice as a carbon source}

The results presented in fig. (1) showed that levan production in the medium contains molass $(65.5 \%$ sucrose) was slightly higher compared with standard production medium (4\% sucrose). Statistical analysis showed that, the sample of $25 \%$ molass was significantly higher compared with other samples at 0.05 significant level, when sucrose substituted with molasses at $25 \%$ led to the significant increase of levan production compared with other substitute percentages, which was 5.2 g.100 $\mathrm{ml}^{-1}$, while the levan production was 4.9, 4.8 and 4.1 for substitute percentages 50, 75 and 100 respectively. The lowest levan production was found when sucrose was substituted completely with molasses, the lowest levan production was found when sucrose was substituted completely, (Duplicate sentence) and this might be attributed to containing molasses high levels of total sugars, which inhibited bacteria. Previous studies indicated, that sucrose acted as a substrate in the production media induced the enzyme Levansucrase that led to increase in levan production in cells.

Increasing sucrose concentration in media led to increasing fructose concentration, subsequently increase the levan level (Dos Santos et al., 2013). The result of this study was in agreed with the results of GojgicCvijovic et al. (2019), when they used molasses $(62.6 \%$ sucrose) as a carbon substitute for sucrose, using B. licheniformis NS032, which found that the growth of this bacteria was very fast when molasses medium was used and the highest production of levan was $5.32 \mathrm{~g}$. $100 \mathrm{ml}^{-1}$. While the results of Silbir et al. (2014) when molasses media was used as a carbon source in production media for the production of levan as the estimated amount of levan produced was about $30 \mathrm{~g} . \mathrm{l}^{-1}$

Data juices presented in fig. (2) revealed the levan production on the media containing date juice as a substitute for sucrose at different percentages, levan production was decreased with the increase of substitute proportion. Date juice contains a high level of glucose and fiber compared with molasses, and that may explain the decrease of levan production, which is affected by the sugar type. The results of this study agreed with the results of Moosavi-Nasab et al. (2010) found that $1.048 \mathrm{~g}$ of levan. $100 \mathrm{ml}^{-1}$ of date juice compared with $48.9 \mathrm{~g}$. $\mathrm{L}^{-1}$ levan production from culture media content sucrose $20 \%$ when fermentation conditions were 48 hours and $\mathrm{pH} 6.0$. 


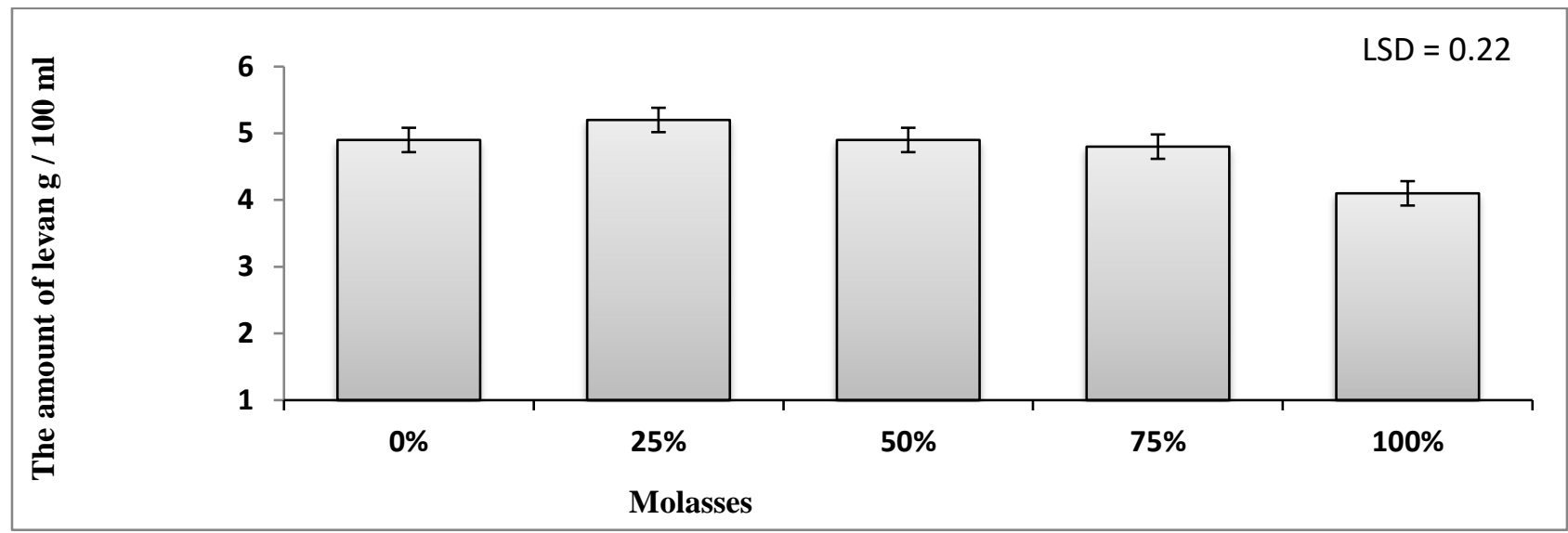

Fig. (1): Effect of using different percentages molasses as carbon source substitute for sucrose $(25,50,75$ and $100 \%)$.

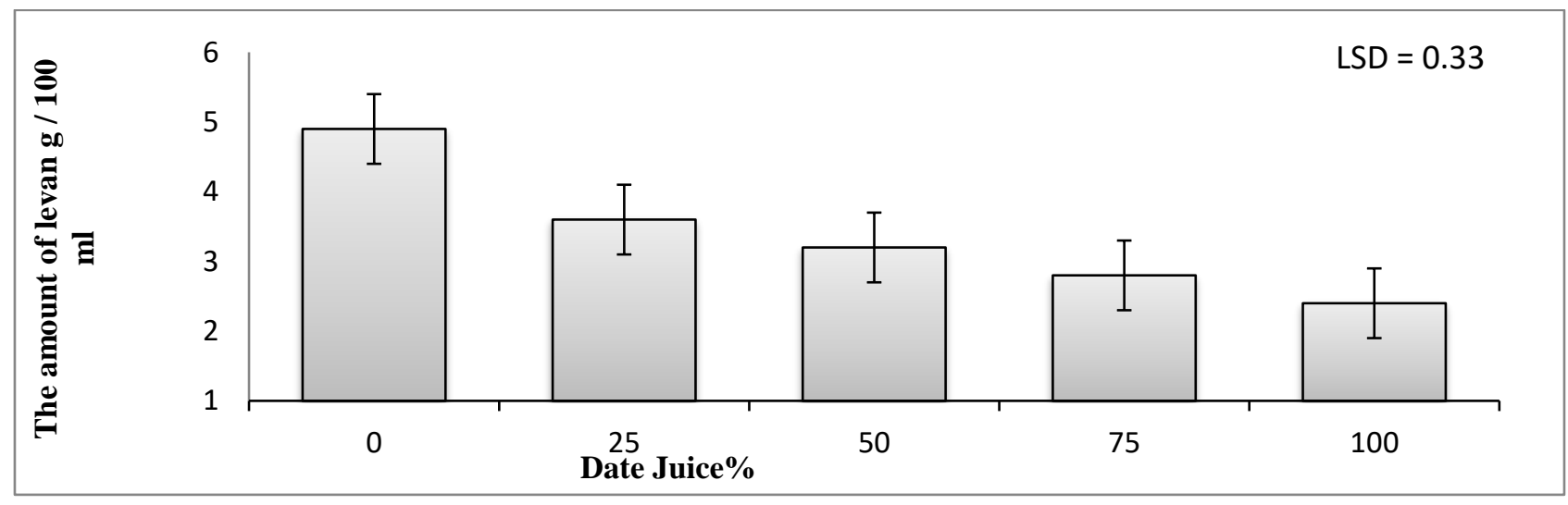

Fig. (2): Effect of Using Different percentages of Date Juice as a carbon source substitute for sucrose $(25,50,75$ and $100 \%)$.

\section{The periods of fermentation}

Fig. (3) shows the periods of fermentation time for levan production, statistical analysis indicates that, incubation time for 40 hours led to a significant increase of levan production compared with other incubation periods, it was $5.5 \mathrm{~g} .100 \mathrm{ml}^{-1}$. In addition, results showed, that the reduction of levan production was decreased with the increase of incubation period. The decrease in productivity with an increase of the incubation time might be have resulted from changes in the production media as low of nutrients, and increased toxins and the possibility of autolysis of bacterial cells that negatively affected he production of levan.
The results of the current study were similar to the results of Dos Santos et al. (2013), which found that the higher levan production was achieved after 38 hours of incubation, and, reported that levan production correlated with fermentation time and sucrose level in the production media. Meanwhile, the results were reversed when the levan level was increased, and the production of levan decreased due to the increase in the viscosity of the medium, which resulted from the presence of levan, which led to the imbalance of osmotic pressure and death of bacterial cells. GojgicCvijovic et al. (2019) reported that the highest 
production of levan was achieved at fermentation period less than 48 hours when molasses used as a carbon sources in production media, which reached 5.32 g.100 $\mathrm{ml}^{-1}$. While Shih et al. (2005) found that, $B$. subtilis (Natto) Takahashi produced higher levan production at 21 hours as a fermentation period, which was $4-5 \mathrm{~g} .100 \mathrm{ml}^{-1}$.

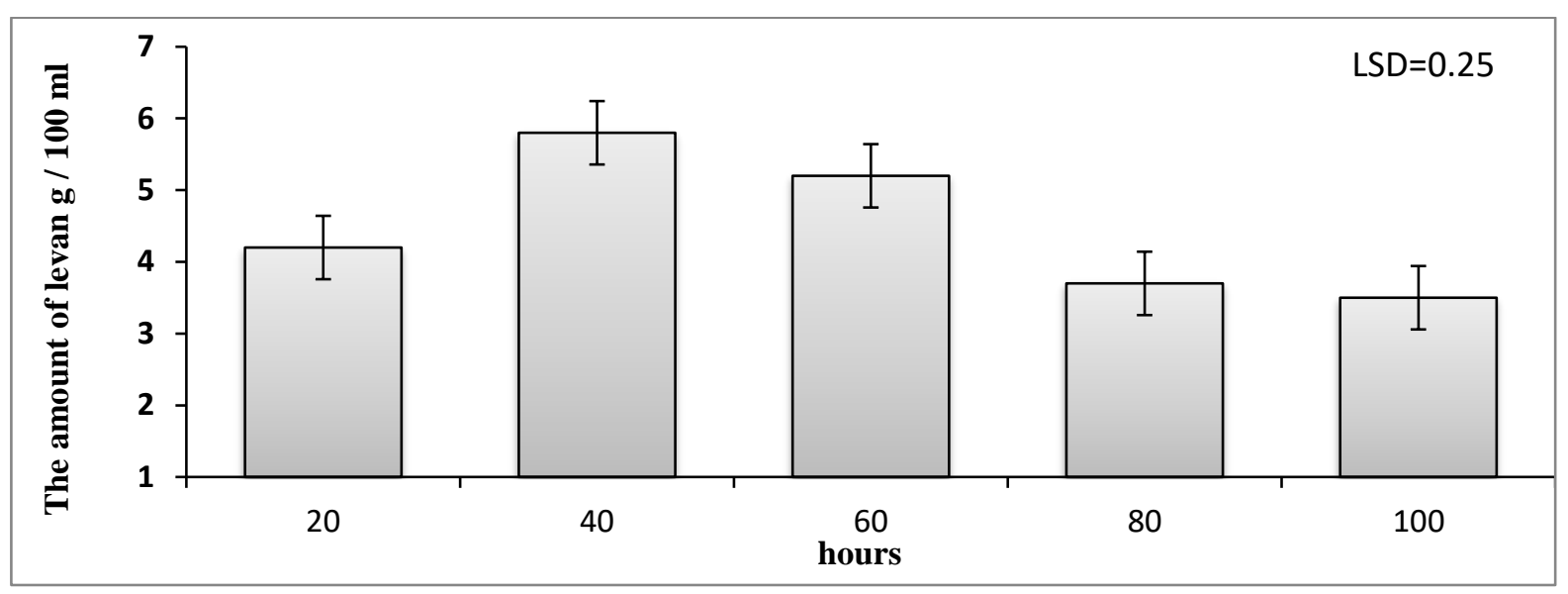

Fig. (3): Effect of different fermentation periods for levan production from molass media by local isolate.

\section{The inoculum volume}

The effect of different inoculum volumes on the levan production was also investigated and presented in fig. (4), the obtained results showed a reduction in levan production with an increase of inoculum volume. The highest levan amount was $6.2 \mathrm{~g} .100 \mathrm{ml}^{-1}$, which produced when an inoculum volume of $1 \mathrm{ml}$. $100 \mathrm{ml}^{-1}\left(129 \times 10^{9}\right)$ colony forms units. $\mathrm{ml}^{-1}$ was used. The reduction in levan production might be due to the increasing growth of cells in the production media, which led to the utilization of nutrients and oxygen in a short time and thus a rapid utilization of sugars in the media and reduced production. These results were in agreement with results of Küçükaşik et al. (2011) they used 1\% inoculum for levan production by Halomonas sp. from molasses media. However, the study

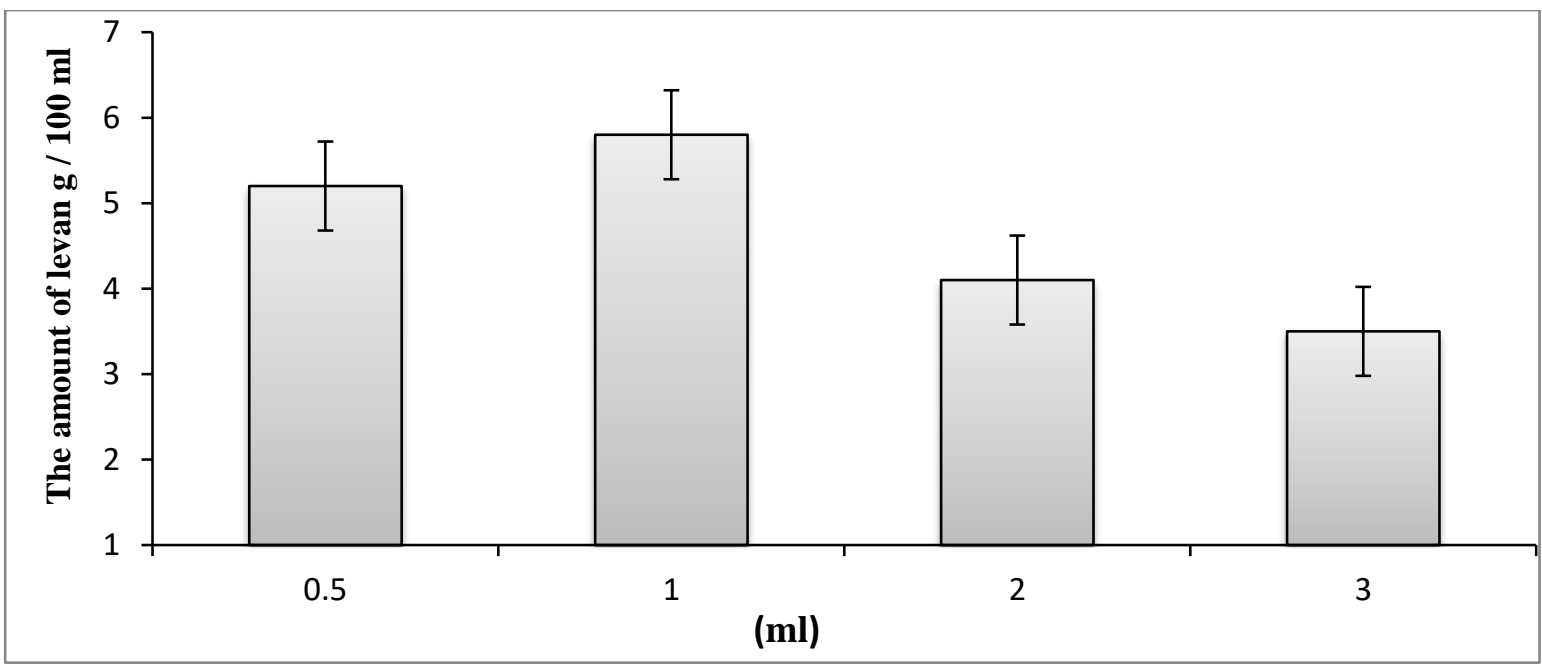

Fig. (4). The inoculum volumes effect on levan production from molass media by local isolate. 
disagree with what some researchers found when $5 \%$ of inoculum volume for the production of levan was used. (Dahech et al., 2014). This might be due to the different isolates in their growth rate and the different times of growth phases for each bacterium and the fact that the isolation used in the study is local and may differ from universal isolates and strains in growth and production.

\section{The fermentation temperature}

Fig. (5) shows the efficiency of local bacterial isolation in its ability to produce levan during incubation at different temperatures. The results showed the maximum amount of levan was produced after 40 hours of incubation at $32{ }^{\circ} \mathrm{C}$ it was $6.2 \%$, this might be due to the activity of levansucrase to converted sucrose into levan, while the productivity was declined when the temperature reached to 50
${ }^{\circ} \mathrm{C}$. The effect of temperature and its suitability for bacterial growth might explain the difference of bacterial isolates in the production of levan. The increase in productivity by increasing or decreasing the temperature was somewhat consistent with the previous research. Dos Santos et al. (2013) verified that $35^{\circ} \mathrm{C}(5.025$ g.100 ml-1) was the optimum condition for levan production from B. licheniformis ANT 179. While Devi \& Alamu (2013) found that, the best temperature for levan production was 37 ${ }^{\circ} \mathrm{C}$, it was $(3.3 \%)$ after 60 hours of incubation. The levan increasing productivity was due to the temperature that was appropriate for bacterial growth and production. Their enzymes that produced their metabolites and because they are local isolates might differ from other universal strains in growth and production.

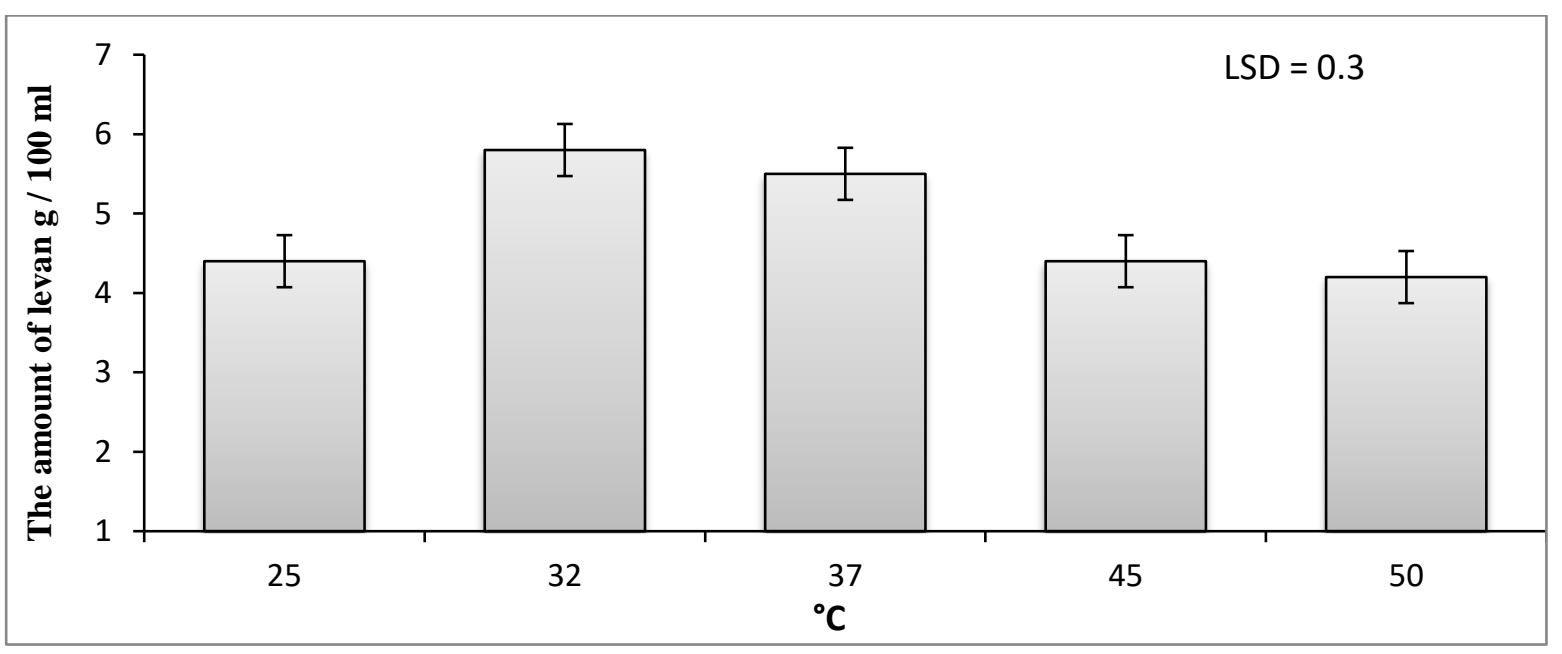

Fig. (5): Effect of incubation at different temperatures on the productivity of levan from a local isolation.

\section{Initial pH}

Fig. (6) shows the effect of the initial $\mathrm{pH}$ of the production media on the production of levan by a local isolate of $B$. subtilis subsp. subtilis w36. It was noticed from the results that, the productivity of levan increased significantly with increasing $\mathrm{pH}$ to 6.5 , it was
6.8 g.100 $\mathrm{ml}^{-1}$. Meanwhile, levan production was decreased when the $\mathrm{pH}$ of the media above 7. The $\mathrm{pH}$ of production media considered as an important factor to controlling of metabolic substances included enzymes (levansucrase which responsible for 
levan formation), and the optimum $\mathrm{pH}$ of Bacillus was 6.5 (Abou-Taleb et al., 2015). Belghith et al. (2012) concluded that The optimal $\mathrm{pH}$ of the levansucrase was 6.5 ,this might be explain increase of levan production. The results of this study were agreed with results of Hamid et al. (2018), they reported the optimum $\mathrm{pH}$ of levan production by $B$. subtilis B58 ranged from 6.2-6.5, on the other hand, these results was disagreement with Gojgic-Cvijovic et al. (2019) who found that the production of levan by $B$. licheniformis NS032 at an initial $\mathrm{pH}$ was 7.2.

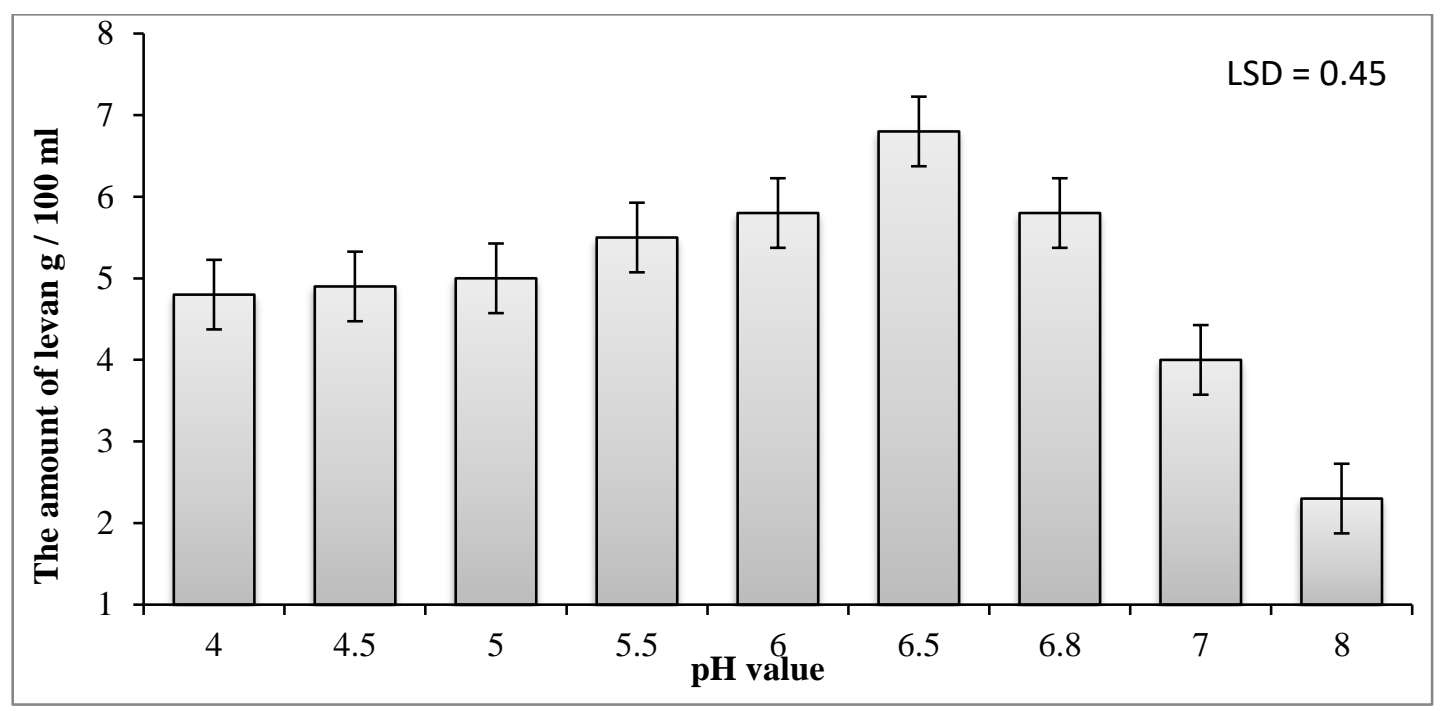

Fig. (6): Effect of pH values on levan production from molass media by local isolate.

\section{Conclusion}

Levan characteristic properties in many fields, such as food, medicine, cosmetics, we have been shown to improve and increase levan production. In that connection, we conducted the present study. Local isolation has proved that $B$. subtilis subsp. subtilis w36 was effective in the production of levan at $4.9 \mathrm{~g}$. $100 \mathrm{ml}^{-1}$. The high cost of levan production led researchers to try to reduce the cost of production using some agricultural ${ }^{-}$wastes instead of sucrose such as molasses, which was used in this study, and the results showed that the substitute percentages of $25 \%$ of molasses gave the highest production. The optimum conditions of levan production were 40 hours fermentation, $1 \mathrm{ml}$ inoculum volume, initial $\mathrm{pH}$ of the medium was 6.5 and the incubation temperature was $32{ }^{\circ} \mathrm{C}$. It produced $6.8 \mathrm{~g}$ of levan from $100 \mathrm{ml}$ of media culture.

\section{Conflicts of Interest}

The authors have declared that there were no conflicts of interest regarding the publication of this paper.

\section{Acknowledgements}

Many thanks to the Staff of Biotechnology Laboratory, Department of Food Science, College of Agriculture, University of Basrah, for the financial support of this study.

\section{References}

Abou-Taleb, K.A.; Abdel-Monem, M.O.; Yassin, M.H. \& Draz, A.A. (2014). Nutritional factors affecting levan production by Bacillus sp. V8 strain isolated from rhizosphere bean (Vicea 
faba) plant. J. Agric. Tech., 10(4): 899914.

Abou-Taleb, K.; Abdel-Monem, M.; Yassin, M. \& Draz, A. (2015). Production, purification and characterization of Levan polymer from Bacillus lentus V8 strain. Brit. Microbiol. Res. J., 5(1): 22-32.

Al-Manhel, A.J. \& Niamah, A.K. (2017). Mannan extract from Saccharomyces cerevisiae used as prebiotic in bioyogurt production from buffalo milk. Int. Food Res. j., 24(5): 2259-2264.

Al-Sahlany, S.T.G. \& Al-Asady,A.K. (2015). Study of optimum condition for Polyhydroxybutyrate from local isolate of Bacillus cereus B5 bacteria.U. Thi-Qar J.Sci., 5(2): 88-96.

Belghith, K.S.; Dahech, I.; Belghith, H. \& Mejdoub, H. (2012). Microbial production of levansucrase for synthesis of fructooligosaccharides and levan. Int. Biol. Macromol., 50(2): 451-458.

Bersaneti, G.T.; Pan, N.C.; Baldo, C. \& Celligoi, M.A. P.C. (2018). Co-production of fructooligosaccharides and levan by levansucrase from bacillus subtilis natto with potential application in the food industry. Appl. Biochem. Biotech., 184(3): 838-851.

Dahech, I.; Bredai, R. \& Srih, K. (2014). Optimization of levan production from Bacillus licheniformis using response surface methodology.Biochemistry, 8(4): 115-119.

Dalaly, B. \& Al-Hakim, S. (1987). Food Analysis. Univ. Mosul, Iraq: 563pp. (In Arabic).

Devi, G.K. \& Alamu, A. (2013). Production of biopolymer levan by Bacillus subtilis using non-ionic surfactants. Asian J. Pharm. Tech., 3(4): 149-154.

Divya, J.M. \& Sugumaran, K.R. (2015). Fermentation parameters and condition affecting levan production and its applications. J. Chem. Pharm. Res., 7(2): 861-865.

Dos Santos, L.F.; De Melo, F.B.C.; Paiva, W.M.; Borsato D.; Da Silva, M.C.C. \& Celligoi, M.P.C. (2013). Characterization and optimization of levan production by Bacillus subtilis NATTO. Rom. Biotech. Lett., 18(4): 08413.

Franken, J.; Brandt, B.A.; Tai, S.L. \&Bauer, F.F. (2013). Biosynthesis of levan, a bacterial extracellular polysaccharide, in the yeast Saccharomyces cerevisiae. PloS one, 8(10): e77499.

Gojgic-Cvijovic, G.; Jakovljevic, D.; Loncarevic, B.; Todorovic, N.; Pergal, M.V.; Ciric, J.; Loos, K.; Beskoski, V.P. \& Vrvic, M. (2019). Production of levan by Bacillus licheniformis NS032 in sugar beet molasses-based medium. Int. J. Biol. Macromol., 121: 142-151.

Gu, Y.; Zheng, J.; Feng, J.; Cao, M.; Gao, W.; Quan, Y.; Dang, Y.; Wang, Y.; Wang, S.\&Song, C. (2017). Improvement of levan production in Bacillus amyloliquefaciens through metabolic optimization of regulatory elements. Appl. Microbiol. Biot., 101(10): 4163-4174.

Hamid, K.; Elsayed, E.; El Enshasy, H.; Esawy, M. \& Malek, R.A. (2018). Bioprocess optimization for levan production by Bacillus subtilis B58. J. Sci. Ind. Res., 77: 386-393.

Jathore, N.R.; Bule, M.V.; Tilay, A.V. \& Annapure, U.S. (2012). Microbial levan from Pseudomonas fluorescens: Characterization and medium optimization 
for enhanced production. Food Sci. Biotechnol., 21(4): 1045-1053.

Küçükaşik, F.; Kazak, H.; Güney, D.; Finore, I.; Poli, A.; Yenigün, O.; Nicolaus, B. \& Öner, E.T. (2011). Molasses as fermentation substrate for levan production by Halomonas sp. Appl. Microbiol. Biot., 89(6): 1729-1740.

Meng, G. \&Fütterer, K. (2003). Structural framework of fructosyl transfer in Bacillus subtilis levansucrase. Nat. Struct. Mol. Biol., 10(11): 935.

Moosavi-Nasab, M.; Layegh, B.; Aminlari, L. \&Hashemi, M.B. (2010). Microbial production of levan using date syrup and investigation of its properties. World Acad. Sci., Eng. Tech., 44(2010): 1248-1254.

Santos, V.A.Q.; del Bianchi, V.L.; GarciaCruz C.H. (2014). Effect of initial pH in levanproductionby Z. mobilis immobilized in sodium alginate, Acta Sci- Technol., 36(2): 349-354.

Shih, I.L.; Yu; Y.T.; Shieh, C.J. \& Hsieh, C.Y. (2005). Selective production and characterization of levan by Bacillus subtilis (Natto) Takahashi. J. Agr. Food Chem., 53(21): 8211-8215.

Silbir, S.; Dagbagli, S.; Yegin, S.; Baysal, T. \& Goksungur, Y. (2014). Levan production by Zymomonas mobilis in batch and continuous fermentation systems. Carbohyd. Polym., 99: 454-461.

Srikanth, R.; Reddy, C.H.; Siddartha, G.; Ramaiah, M.J. \& Uppuluri, K.B. (2015a). Review on production, characterization and applications of microbial levan. Carbohyd. Polym., 120: 102-114.

Srikanth, R.; Siddartha, G.; Reddy, C.H.S.; Harish, B.; Ramaiah, M.J. \& Uppuluri, K.B .(2015b). Antioxidant and antiinflammatory levan produced from Acetobacter xylinum NCIM2526 and its statistical optimization. Carbohyd. Polym., 123: 8-16.

Tomulescu, C.; Stoica, R.; Sevcenco, C.; Căşărică, A.; Moscovici, M. \& Vamanu, A. (2016). Levan-a mini review. Sci. Bull. Ser. F. Biotecnol., 20: 309-317. 